\title{
Discussion on the Inheritance and Transcendence of Kant's Rationalism to Hume
}

\author{
Xue Bai \\ School of Humanity and law, Yanshan University, Qinhuangdao, Hebei, 066004, China \\ 1205121044@qq.com
}

Keywords: Hume, Kant, Rationalism, Empiricism.

\begin{abstract}
Kant's critical philosophy, created the classical philosophy of German as a new period of development, and promoted the arbitrary end of rationalism and empiricism philosophy. It is the philosophy of Hume's skepticism that played an important role in the intermediary and the connection between the old and new philosophy. Based on the study of Hume's influence on Kant, this paper focuses on the analysis of Hume's influence on Kant by criticizing metaphysics and the influence of Hume's skepticism on Kant. Secondly, Hume provided a new direction to Kant's philosophy thought, pushing him further deliberation. So in the second part of this article, the author would explore problems that Kant solved for Hume, and do further analysis of the rationalism of Hume's inheritance and transcendence.
\end{abstract}

\section{Hume - one of the Sources of Kant's Philosophy}

Kant's critical philosophy initiated a new period of the development of German classical philosophy and promoted the end of dogmatic rationalism and empiricism. Hume's skeptical philosophy played an important role in the mediation and connection between the two new philosophies. Hume's empiricism and agnosticism, exposed the absurdity of traditional religious idealism, and explicitly put forward the modern philosophy of science and religion, reason and experience, also inspired Kant going out of dogmatism rationalism, then went on the road of critical philosophy. It can be said that Hume's philosophy was one of the ideological sources of Kant's philosophy and was also an important turning point in the development of western philosophy from arbitrary rationalism and empiricism to German classical philosophy.

\subsection{Hume's Criticism of the Influence of Metaphysics on Kant}

One of Kant's most fundamental questions was whether metaphysics was possible and correct or not. Kant's purpose was to build new metaphysics on the basis of criticizing the original metaphysics, and the negative criticism of his metaphysics affected Kant, prompting him to solve and prove the rationality of metaphysics.

Hume's attitudes to metaphysics were critical and negative. He held that metaphysics was not a true science. Metaphysics came from the superstition of human spirit and the philosophy of skepticism. The primary purpose was to oppose and deny metaphysics. This was also his starting point for the important influence of Kant's philosophy which was skepticism. Taking the logic of human cognitive thinking as the starting point, he analyzed and demonstrated the rationality of metaphysics so that he could go to school from the root. He believed that the eradication of metaphysics was to draw a line between rational knowledge and metaphysics. From the analysis of rational thinking, it was not only a science to prove metaphysics, but also a kind of thinking inertia. Hume believed that knowledge was divided into mathematical deduction and experience induction. In addition to mathematical deduction, all activities of human thinking must be based on facts, and all cognition of actual things came from causality. Metaphysics was based on this to deduce and construct. Hume believed that the concept of entity did not exist. We had only two kinds of knowledge about the outside world: the relationship between ideas and facts. At this time, the relationship between "conceptual association" and "concept (actually)"should be distinguished. Therefore, the focus of Hume's philosophical research was causality, and it mainly studied the 
discovery, essence and inferential conditions of the concept of causality. He also believed that the link between a factual cause and the result was a reflection of experience rather than an inevitable link that can be scientifically calculated. The general connection of some things in real life was the habitual association based on experience rather than rational inference. Hume thought that experience was the reason. Metaphysics was a kind of truth and science that mistakenly thought of concept. Its essence was illusory and absurd, and it was not enough to form scientific knowledge.

Hume's criticism of metaphysics complied with the needs of the development of the times and philosophy, gave the metaphysics a heavy blow, and also inspired Kant's critical study of metaphysics. As Kant said, "I confess frankly that Hume's hints first broke my dogmatism dream years ago and gave me a completely different direction in my study of speculative philosophy."[1] Kant was a faithful disciple of Leibniz Wolf's theory of metaphysics. Hume criticized the Metaphysics from the causation and rational knowledge, which made Kant realized the dictatorial and illusory nature of the old metaphysics, and promoted the rationality of Kant to present and question the traditional metaphysics. It was possible to bring new defense to metaphysics. Besides, Hume criticized the old metaphysics and denied the existing foundation of Metaphysics from the fundamental possibility. This also prompted Kant to face this important proposition and regarded "metaphysics as a science" as an important task of his philosophical research. Hume's metaphysical possibility raised from the perspective of epistemology. It has brought Kant a new research direction and starting point [2], inspiring Kant to explore the forming conditions and boundaries of knowledge logic from the possible analysis of rationalism, and brought a new life to Metaphysics from the dual angle of experience and reason.

\subsection{The Influence of Hume's Skepticism on Kant}

One of the most important part of Hume's philosophy was the criticism of God's religion and idealism, which also had an influence over Kant's critical philosophy to a large extent. Hume put skepticism into the field of religion, first of all, he questioned the method of God's existence. He believed the concept of "God's existence" what can not be derived from empirical reasoning, that is to say, the existence of God can not be determined by rational inference. The question of whether God exists or not is fact and fact can not be deduced by reasons. Then we can not deny the possibility that God does not exist. Hume further ventured to suggest that the concept of God came from the subjective impression of man. Religion was neither science and knowledge, nor the object of human understanding. Secondly, Hume, starting from the theory of empiricism, denied God's cosmic authority, and believed that experience and science were sufficient to explain the role and movement of natural things. In his view, people did not have the experience of God's dominating nature, so we can deny the ability and function of God, and the nature found by experience and natural science. Regularity was enough to explain natural phenomena and material movement [3]. Hume's views affirmed human nature and science, and embodied the spirit of humanism. Hume's skepticism put the opposition between religion and science, belief and reason, and denied the rule of God, also divided the religion from the knowledge science, together with affirming the rational and scientific authority of human beings. From the question of science and religions, reasons, man and God, Kant revealed the mistakes and illusory of old metaphysics by proving metaphysics was not the object of scientific knowledge, so as to remove theology out of the field of science and lay a foundation for further pioneering of the classical philosophy of German.

At the same time, when Hume criticized the religion, he carried forward the human nature, also transformed the object of philosophy from God to man, and established man as the basis of all science. He believed that all the sources of science were not the Gods or the objective things, but the reasons and the understandings of human beings. Therefore, Hume advocated that human nature was the fundamental starting point of philosophical research and the foundation of real philosophy, which was Hume's philosophical view of "human nature". This view of humanity as the object and foundation of philosophical research embodied the transformation of subject and object of modern philosophy. Kant's philosophical viewpoint was also inspired by Hume's "theory of human nature" and affirmed the ability of human initiative to master and transform nature. Kant once said that his philosophy solved four questions. Firstly, what can I know? What do I know? Secondly, what should 
I do? Thirdly, what can I hope? Fourthly, what are people? Around these questions, Kant fully affirmed human freedom and reason, and tried to take "man" as the starting point to study solutions to the major problems of human history. [4] Thus, it was concluded that Hume's skepticism, his critique of theology gave inspiration to Kant's critical philosophy, and provided a breakthrough point for methods and criticism.

\section{The Development of Kant's Rationalism to Hume}

Kant has made it clear that Hume provided a direction and thought to his philosophical speculation. He did not approve Hume's philosophical conclusions, because Hume did not look at problems in a comprehensive way and had limitations in philosophy, and the positive influence of Hume's philosophy on himself was to further deliberate and solve. The question has been put forward by Hume.

Kant believed that Hume's skepticism was developed from empiricism, and Hume's empiricism denied the positive role of reason in experience or fact and any objectivity and inevitability of experience. In Hume's empiricism, there was no innate concept and metaphysics, which gave Metaphysics a heavy blow from the rational level. Although Kant did not agree with Hume's conclusion on metaphysics, he believed that this work of Hume had positive significance for breaking old metaphysics and constructing scientific metaphysics. Hume eliminated rationality from experience, and Kant thought Hume ignored the priority of things. In this respect, the method he adopted was the synthesis of empiricism and rationalism. Kant must prove that the concept of reason can be reasonably used in the object of experience. Some of the cognitive abilities of human beings were preceded by experience and independent from experience. This was the congenital rational concept [5]. This was also Kant's transcendental philosophy.

The main component of Kant's transcendental philosophy was causality. In Kant's view, Hume's causality argument has attacked the metaphysics of dogmatism, but has gone to the way of extreme skepticism. Also, Hume's causality separated experience from reason, neglecting the role of reason. He cited an example as followed, "heat always follows the sun after drying stones". Therefore, the experience proposition was always accidental. As for heat, the heat was bound to come from the sun, which was contained in empirical judgment (by means of causality), but this was not what experience has told us; on the contrary, the creation of experience, was due to the sense of reason (the concept of causality). " [6] so in Kant's view, Hume only saw one side of the problem, and he did not really solve the problem of causality. Also he not only negated metaphysics, but also destroyed science to some extent. Kant decided to take a new path which was different from Hume. He advocated that in the causality, there was a division of labor between experience and reason. The two could not be replaced by each other, and rationality had an unquestionable objective accuracy. Kant absorbed the rational elements in the empiricism of the causality in Hume's philosophy, and expanded the scope of the study of the concept of causation with the objectivity and inevitability of rationalism. It can be said that Hume's theory of cause and effect directly prompted Kant to establish transcendental philosophy and build his own philosophical system through the study of this problem.

Hume once said that "reason is not the only motive that affects our behavior, even it is not an important motive". The function of reason was limited to correcting our false ideas or beliefs, and determining effective means to achieve a goal."Kant thought that Hume's thinking about philosophical concepts was one-sided, and he only saw the concept category in experience, but did not see the rational part. In essence, it ignored the unity of opposites between experience and reason. But Hume's point of view inspired him to come out of the rationalist riddle, and made him realize that in order to solve the problems raised by Hume, he must give priority to the category of perceptual experience and rational thinking. Kant's rationalism held that cognition was a process from sensibility to intellectuality, and intellectuality to reason. This process was indivisible and irreversible. He acknowledged that experience was the source of ideas and the object of ideas. But rationality was a necessary condition for experience to function. Experience can not become universal knowledge without logical deduction. That is to say, if causality was to be applied in practice, it must be 
processed by reason. On Hume's philosophical issue, Kant solved and remolded from his own philosophical system, transcending Hume, which was exactly the of Kant's contribution [7].

In summary, Hume threw out a question and made an answer. Kant got the question, questioned the answer, and gave his answer. Hume criticized metaphysics, reason and science. Kant has been inspired by Hume's empiricism and absorbed the rationalist ideas of other philosophies. Both criticizing and inheriting Hume, Kant acknowledged the integrated unity of the object and the logical identity of the self, also admitted the existence of the innate comprehensive proposition, and unified empiricism and rational science in their own criticism. Generally speaking, in the system of philosophy, Kant's objective and dialectical treatment of Hume's philosophical theory were both inheritance and development.

\section{Conclusion}

The emergence of Kant's philosophy represented the arrival of a period of German classical philosophy. One of the basic starting points of his theory was that the reason for transforming experience into knowledge (i.e. category) was human and that we can not understand the world without the innate category. Hume has played an important role in the formation of Kant's philosophical system. Hume's theory of causation and skepticism made Kant out of the theory of independence and led Kant to further develop his rationalist philosophy. In his own philosophical world, Kant answered the questions in depth which raised by Hume, that is, Hume's "Mars" brought Kant "light". Kant's criticism, inheritance. And development of Hume also enlightened us that the practical significance of the works of the philosophers from the ancient to the present was what they all made a survey of the times, putting forward the problems and trying to solve them, which also enlightened us from them solving the problems and criticizing the problems from their own standpoint. Then they constructed their own concept framework and system to better thinking and solving the current problems.

\section{References}

[1] Kant: Critique of pure reason, translated by Deng Xiaowang, People's Publishing House, 2004 edition.

[2] Chen Xiaoping. On the rationality of induction: Kant's solution to Hume's problem and its improvement [J]. Natural Dialectics Study.2010 (2): 4-9

[3] David Hume: Theory of human nature, translated by Guan Wen, Beijing Business Press, 2005 edition.

[4] Kant: The basis of metaphysics of natural science, translated by Deng Xiaowang, Shanghai People's Publishing House, 2003 edition.

[5] Jiang Zhaoyang. Normative defense and motivation explanation -- differences between Kant and Hume and their contemporary bridging [J]. Journal of Xiamen University (PHILOSOPHY AND SOCIAL SCIENCES).2014 (5): 95-103

[6] Kant: Deng Xiaowang's translation of critique of practical reason, Beijing People's Publishing House, 2004 edition.

[7] Bernard Bourgeois: German classical philosophy, translated by Deng Gang, proofread by GAO Xuanyang, People's Publishing House, 2013 edition. 